\title{
Effectiveness of premarital screening program for thalassemia and sickle cell disorders in Ras Al Khaimah, United Arab Emirates
}

\author{
Rasha Aziz Attia Salama, ${ }^{1,2, *}$ and Abeer Kamal Saleh ${ }^{1}$ \\ ${ }^{1}$ Department of Community Medicine, Ras Al Khaimah Medical and Health Science University, Ras Al Khaimah, United Arab Emirates \\ ${ }^{2}$ Department of Public Health and Community Medicine, Kaser El Aini School of Medicine, Cairo University, Cairo, Egypt
}

Purpose: Genetic disorders can be prevented by basic public health measures and activities that focus primarily on education and approaches in Primary Health Care. Premarital screening is one such approach that can identify asymptomatic carriers of hemoglobinopathies and provide genetic counseling to couples for a healthy reproductive life. This study aimed to estimate the prevalence of beta thalassemia and sickle cell disorders in the adult population screened as a part of the United Arab Emirates Premarital Screening Program and to measure the effectiveness of the program in decreasing high-risk marriages in Ras AI Khaimah (RAK).

Materials and Methods: A retrospective, population-based study was conducted at the RAK Primary Health Care Center, where the National Premarital Screening Program is implemented. The study included data collected from the premarital screening records of all couples who had applied for a marriage license during 2008-2015.

Results: Of the 17,826 individuals screened during the studied period, $4.02 \%$ (717) were diagnosed as positive for hemoglobinopathies. The prevalence of beta thalassemia and sickle cell disorders among the total study population was $2.98 \%$ and $1.05 \%$, respectively. The hemoglobinopathy trait was more prevalent than the disease. Among these 8,913 couples who were issued certificates for compatibility based on screening tests, $28(0.31 \%)$ couples were declared high-risk (unmatched). Seventy percent of these unmatched couples reported consanguineous marriages.

Conclusion: The program was successful in achieving its objective of identifying high-risk marriages. In spite of the counseling, however, all of the high-risk couples still married each other.

Key words: Premarital screening, Beta thalassemia, Sickle cell disorders, United Arab Emirates.

\section{Introduction}

Thalassemia and sickle cell disorders are genetic blood diseases that affect how oxygen is carried in the body [1]. Both conditions are due to the inheritance of mutant hemoglobin genes from apparently healthy parents. Available epidemiological data clearly indicate that genetic disorders are rapidly becoming a major public health concern in certain parts of the world [2]. According to the World Health Organization in 2012, approximately $5 \%$ of the world's population carries trait

\footnotetext{
Received: 16 February 2016, Revised: 9 May 2016, Accepted: 9 May 2016, Published: 30 June 2016

*Corresponding author: Rasha Aziz Attia Salama, M.D., Ph.D.

Department of Community Medicine, Ras Al Khaimah Medical and Health Science University, Al Juwais, Al Qusaidat, Ras al Khaimah 11172, United Arab Emirates. Tel: +971-7-2269000, Fax: +971-7-2269997, E-mail: rashasalama_71@yahoo.com

Conflict of interest: The authors declare that they do not have any conflicts of interest.

(ac) This is an open-access article distributed under the terms of the Creative Commons Attribution Non-Commercial License (http://creativecommons.org/licenses/by-nc/4.0/) which permits unrestricted non-commercial use, distribution, and reproduction in any medium, provided the original work is properly cited.

(c) Copyright 2016 by the Korean Society of Medical Genetics 
genes for hemoglobin disorders, mainly sickle cell disease and thalassemia. Over 300,000 children with severe hemoglobin disorders are born each year, with 80\% born in developing countries [1,3].

In the Gulf region, inherited blood disorders (specifically, thalassemia and sickle cell disease) are highly prevalent and cause great suffering to afflicted children in these countries [4]. The magnitude of the problem can be attributed to two major factors. One is the strong cultural preference for consanguineous marriage, which is associated with a relatively high prevalence of recessively inherited disorders. The other is the large family sizes, which may increase the number of affected children [5]. According to information revealed by the Ministry of Health and the Arab Centre for Genetic Studies in 2007, the number of hereditary diseases in the United Arab Emirates (UAE) had reached to 240, of which 82 diseases resulted from consanguineous marriages. It has been estimated that about $50 \%$ of the marriages in the country are consanguineous, of which 26\% are first-degree marriages [6]. The incidence of beta thalassemia was estimated to be around $8 \%$ in the UAE [7].

Since the 1950s, Arab countries have made great progress in some health-related aspects such as access to health care, life expectancy, and infant mortality. Genetic and congenital disorders are responsible for a considerable number of perinatal and neonatal deaths in Arab populations. In addition to the health effects, they pose severe social, financial, and psychological difficulties that significantly impact the quality of life of the affected individuals and their families [4]. The health burden of these disorders can be effectively reduced through prevention programs focused primarily on education and by approaches in Primary Health Care [2]. Premarital screening is one such approach that can accurately identify asymptomatic carriers of hemoglobinopathies and provide genetic counseling to couples for a healthy reproductive life. This program can greatly reduce the rate of high-risk marriages and the birth of affected infants, provided that social, religious, ethnic, and cultural factors are all addressed [8]. Premarital screening services in the UAE were initiated with the Marriage Fund in 1992. This program provides UAE nationals, intending to get married, with adequate support in terms of financial grants and family guidance services. Its aim is to prepare and guide prospective couples toward starting a stable family life and building a solid UAE society [9]. Since 2009, the UAE Ministry of Health has legislated mandatory premarital screening for all couples planning to get married, not only for those applying for the marriage fund. A medical certificate, which is valid for three months, has to be submitted to the judicial department before a marriage can proceed $[10,11]$.

Several countries in the Mediterranean and Middle Eastern regions have also implemented mandatory premarital screening and genetic counseling programs to reduce the prevalence of genetic disorders. This current study aimed to estimate the prevalence of sickle cell disorders and beta thalassemia in the adult population screened as part of the Premarital Screening Program and to assess the effectiveness of the program in decreasing high-risk marriages in Ras AI Khaimah (RAK), UAE.

\section{Materials and Methods}

\section{Data background and setting}

The data used in this study were acquired from the RAK Primary Health Care Center, previously known as El Kuwaiti Hospital. This is the only center that has been authorized by the UAE Ministry of Health to implement the premarital screening program in RAK. It provides testing and counseling services to all couples planning to get married and applying for a marriage license. The tests are free for Emiratis, but have to be paid for by non-citizen residents. Insurance does not cover the premarital testing. The prospective couples have to contact the designated center, where trained staff (usually pediatricians, but if not available, a designated physician) will record their basic demographic information and collect the blood samples into tubes (containing ethylenediamine tetraacetic acid anticoagulant) for testing at the designated laboratory. Hemoglobinopathies are identified via hemoglobin electrophoresis, and the results are interpreted in accordance with standard laboratory diagnostic protocols [12].

Couples found to have a low risk of hemoglobinopathy are issued compatibility certificates. However, if both members of the prospective couple are found positive for sickle cell trait/ disease and/or thalassemia trait/disease, they are declared highrisk. These couples are not issued a marriage certificate and are referred to genetic counseling in the same clinic. The counseling is given either to the couple likely to get married or to the male partner along with a person representing the female. The counseling session includes discussion on the risk of having children with a severe form of disease and its consequences. A certificate of incompatibility is issued to both partners after obtaining their signatures and providing them with health education brochures. Couples have the right to marry regardless of the screening test results. All the high-risk couples are being followed up to evaluate the success of the program. 


\section{Study design and data collection}

This retrospective, population-based study included all individuals who had applied for a marriage license during the years 2008-2015. The data were collected from the available premarital screening records obtained at the RAK Primary Health Care Center. Information regarding the total number of persons tested, demographic characteristics, positive cases and carriers of hemoglobinopathies, and number of unmatched couples were obtained from the program office. However, no personal identification information was transmitted along with these data. The UAE health authorities and the local institutional ethics committee approved the content of the study before it was conducted.

\section{Statistical analysis}

The data were entered into an IBM compatible computer, using the Microsoft Excel Office 2003. Descriptive analysis using frequency counts and percentages was carried out.

\section{Results}

A total of 17,826 individuals were screened under the program from January 2008 to March 2015. The total number of individuals identified with hemoglobinopathies was 717 (4.02\%) (Table 1). More than two thirds (86.5\%) of these individuals were Emirati and more than half of them (57\%) were male.

The prevalence of thalassemia and sickle cell disorders among the total number of adults screened was 2.98\% (531) and 1.05\% (188), respectively. The total number of individuals identified with sickle cell trait was $180(1.01 \%)$ and those with sickle cell disease amounted to $8(0.04 \%)$. In the case of beta thalassemia, 513 (2.88\%) of the individuals screened were found to be positive for the trait and $18(0.10 \%)$ were positive for the disease (Table 1).

Among the 8,913 couples who were issued certificates for compatibility based on screening tests, 28 (0.31\%) were declared high-risk (unmatched). The prevalence of thalassemia was higher than that of sickle cell disorders in the unmatched couples (Table 2). The percentage of consanguineous marriages among all the unmatched couples was 70\%. All the unmatched couples were contacted by telephone, and it was found that $100 \%$ of them had married each other, despite the known incompatibility status.

\section{Discussion}

As determined from this study, the overall prevalence of

Table 1. Prevalence of hemoglobinopathies among screened premarital adults

\begin{tabular}{|c|c|c|c|c|c|c|}
\hline Year & Hemoglobinopathies & Thalassemia trait & Thalassemia disease & Sickle cell trait & Sickle cell disease & Total \\
\hline $2008-2015$ & $717(4.02)$ & $513(2.88)$ & $18(0.10)$ & $180(1.01)$ & $8(0.04)$ & 17,826 \\
\hline 2008 & $91(4.22)$ & $53(2.46)$ & $4(0.19)$ & $32(1.48)$ & $2(0.09)$ & 2,158 \\
\hline 2009 & $119(4.31)$ & $90(3.26)$ & $5(0.18)$ & $23(0.83)$ & $1(0.04)$ & 2,764 \\
\hline 2010 & $107(4.03)$ & $76(2.86)$ & $4(0.15)$ & $26(0.98)$ & $1(0.04)$ & 2,658 \\
\hline 2011 & $111(4.14)$ & $70(2.61)$ & $5(0.19)$ & $34(1.27)$ & $2(0.07)$ & 2,682 \\
\hline 2012 & $92(4.28)$ & $67(3.12)$ & $0(0.00)$ & $25(1.16)$ & $0(0.00)$ & 2,148 \\
\hline 2013 & $105(3.85)$ & $83(3.05)$ & $0(0.00)$ & $21(0.77)$ & $1(0.04)$ & 2,724 \\
\hline $2014-2015$ & $92(3.42)$ & $73(2.71)$ & $0(0.00)$ & $18(0.67)$ & $1(0.04)$ & 2,692 \\
\hline
\end{tabular}

Values are presented as number (\%).

Table 2. Percentage of unmatched couples by hemoglobinopathies disorders

\begin{tabular}{|c|c|c|c|c|}
\hline Year & Total couples & Unmatched couples & Thalassemia disorders & Sickle cell disorders \\
\hline 2008 & 1,079 & $2(0.19)$ & $1(0.09)$ & $1(0.09)$ \\
\hline 2009 & 1,382 & $6(0.43)$ & $5(0.36)$ & $1(0.07)$ \\
\hline 2010 & 1,329 & $2(0.15)$ & $1(0.08)$ & $1(0.08)$ \\
\hline 2011 & 1,341 & $7(0.52)$ & $7(0.52)$ & $0(0.00)$ \\
\hline 2012 & 1,074 & $6(0.56)$ & $5(0.47)$ & $1(0.09)$ \\
\hline 2013 & 1,362 & $3(0.22)$ & $2(0.15)$ & $1(0.07)$ \\
\hline 2014-2015 & 1,346 & $2(0.15)$ & $1(0.07)$ & $1(0.07)$ \\
\hline 2008-2015 & 8,913 & $28(0.32)$ & $22(0.25)$ & $6(0.07)$ \\
\hline
\end{tabular}

Values are presented as number (\%). 
beta thalassemia and sickle cell trait/disease was quite high and resulted in incompatibility in more than $0.3 \%$ of the couples. These figures are much higher than those reported from western countries and may be considered similar to other studies conducted in the Gulf Cooperation Council countries, which have also shown a relatively high prevalence of hemoglobinopathies. A study in Saudi Arabia demonstrated that of a total of 488,315 individuals screened, $4.20 \%$ had sickle cell trait, $0.26 \%$ had sickle cell disease, $3.22 \%$ had thalassemia trait, and $0.07 \%$ had thalassemia disease. Among the couples who were issued certificates for matching, 2.14\% were declared high-risk [13]. The UAE has demonstrated a 0.07\% prevalence of sickle cell disease and 1.5\% prevalence of sickle cell trait among neonates [14]. An Omani study showed a $0.2 \%$ prevalence of sickle cell disease, $6 \%$ prevalence of sickle cell trait, and $2 \%$ prevalence of beta thalassemia among children younger than 5 years of age [15]. These estimates are not directly comparable to our study population, however, because they are figures for neonates or young children. The prevalence of hemoglobinopathies in our study population is not only dependent on the incidence of the disease at the time of conception, but also on the product of the disease incidence and the survival pattern of affected individuals up to the age of marriage. As this survival pattern is dependent on the severity of illness, as well as health care service availability and use, the prevalence of sickle cell disease and thalassemia is low compared with sickle cell trait or thalassemia minor in children.

In developing countries, the major determinants of consanguineous marriages are sociocultural factors, which are resistant to change [16]. A number of other possible reasons include screening at a late stage in the marriage process, difficulty in finding an alternative socially suitable match, commitment of the couple to each other, or failure of the health care staff in providing adequate information to the couples to change their decision. There could be another dimension of possible psychosocial stigma attached to declaring the incompatibility to the community. The Emirati community originated from a tribal society with a high proportion of consanguineous marriages, which means the recessive genes had been able to survive, concentrate, and exhibit disease in these populations over the centuries. This phenomenon has been described as being the major reason for the higher prevalence of autosomal recessive disorders in similar populations [17]. This phenomenon is obvious in the current study, where the prevalence of carriers among Emirati people is high. Seventy percent of the unmatched couples were going through consanguineous marriages and got married to each other despite being aware of the high risk. Indeed, 100\% of the unmatched couples married each other irrespective of the risk of having a child with hemoglobinopathy. Findings in other studies show that programs in Saudi Arabia and Jordan have achieved $10 \%$ and $40 \%$ reductions in at-risk marriage rates, respectively, without legal therapeutic abortion [8]. These increased cancellations of at-risk marriages in the absence of therapeutic termination may be attributed to an increased understanding in these two countries of the problem of genetic blood disorders [18].

Prenatal diagnosis of these diseases is practically unavailable in the current health care system of the UAE. Even if diagnosis were available, the option of abortion is either unavailable or unacceptable to families because of social and/or religious reasons. Considering the fertility pattern of the population and the health care services available, practically all highrisk marriages are likely to produce children at high risk of hemoglobinopathies.

In conclusion, the study results showed an excellent access of the program to the target population in RAK, UAE. The program was successful in screening eligible individuals, identifying the couples at risk of having children with hemoglobinopathies, and providing them with health education. However, it has not been successful in achieving the main goal of discouraging high-risk marriages and decreasing the incidence of these disorders in future generations.

A life-cycle approach to prevention is by offering the screening test to young adults at an earlier stage, such as immediately after high school, so that they can discuss the issue in the early phase of the marriage process. Health education campaigns for the general population and intensification of counseling to high-risk couples are needed to increase awareness of the genetic anomalies and alleviate the associated social biases and unfounded fears. Furthermore, reconsiderations of prenatal detection and therapeutic abortion are likely to improve the effectiveness of such programs.

\section{Acknowledgements}

The authors would like to thank the Primary Health Care Center personnel and the students who helped in the process of data collection for their efforts in this study. 


\section{References}

1. World Health Organization. Sickle-cell disease and other haemoglobin disorders. Fact sheet N³08, 2011 [Internet]. Geneva: WHO, 2011 [cited 2014 Dec 25]. [http://www.who.int/mediacentre/factsheets/fs308/en/]

2. Hamamy $H$, Alwan A. Genetic disorders and congenital abnormalities strategies for reducing the burden in the region. EMHJ 1997;3:12332.

3. World Health Organization. Management of haemoglobin disorders: report of a joint WHO-TIF meeting, Nicosia, Cyprus, 16-18 November 2007 [Internet]. Geneva: WHO, 2008 [cited 2014 Dec 28]. [http:// www.who.int/genomics/WHO-TIF_genetics_fi nal.pdf]

4. Raeburn S. Genetic services in the sultanate of Oman and other Gulf countries: Progress is needed now! Sultan Qaboos Univ Med J 2008;8:129-35.

5. Ahmed S, Saleem M, Modell B, Petrou M. Screening extended families for genetic hemoglobin disorders in Pakistan. N Engl J Med 2002;347:1162-8.

6. Rasheed P. Three years see 52,211 premarital health screenings in UAE. The Gulf Today [Internet]. 2011 Feb 22 [cited 2016 Feb 16]. [http:// p4papyrus.blogspot.ae/2011/02/three-years-see-52211-premaritalhealth.html]

7. Baysal E. Hemoglobinopathies in the United Arab Emirates. Hemoglobin 2001;25:247-53.

8. Alswaidi FM, O'Brien SJ. Premarital screening programmes for haemoglobinopathies, HIV and hepatitis viruses: review and factors affecting their success. J Med Screen 2009;16:22-8.

9. Al Shamsi MS. Message of chairwoman of Marriage Fund Institution [Internet]. Abu Dhabi: Marriage fund UAE, 2015 [cited 2015 Jan 8]. [https://www.zawaj.gov.ae/en/Pages/ChairwomanMessage.aspx]
10. Olarte-Ulherr 0. Pre-marital medical test is mandatory in UAE. Khaleej Times [Internet]. 2012 Jun 6 [cited 2016 Feb 16]. [http://www.commed.vcu.edu/IntroPH/Surveillance/2012/Premaritaltestmandatory.pdf]

11. Ahmad A. Marriage Fund drives to prevent blood disorders calls for premarital tests. Khaleej Times [Internet]. 2010 Jun 12 [cited 2016 Feb 16]. [http://www.khaleejtimes.com/article/20100611/ ARTICLE/306119907/1002]

12. Wild BJ, Bain BJ. Investigation of abnormal hemoglobins and thalassemia. In: Lewis SM, Bain BJ, Bates I, eds. Dacie \&t Lewis practical hematology. 9th ed. London: Churchill Livingstone, 2001:231-68.

13. Alhamdan NA, Almazrou YY, Alswaidi FM, Choudhry AJ. Premarital screening for thalassemia and sickle cell disease in Saudi Arabia. Genet Med 2007;9:372-7.

14. Al Hosani H, Salah M, Osman HM, Farag HM, Anvery SM. Incidence of haemoglobinopathies detected through neonatal screening in the United Arab Emirates. East Mediterr Health J 2005;11:300-7.

15. Al-Riyami A, Ebrahim GJ. Genetic blood disorders survey in the sultanate of oman. J Trop Pediatr 2003;49 Suppl 1:i1-20.

16. Hussain R. Community perceptions of reasons for preference for consanguineous marriages in Pakistan. J Biosoc Sci 1999;31:449-61.

17. Madi SA, Al-Naggar RL, Al-Awadi SA, Bastaki LA. Profile of major congenital malformations in neonates in Al-Jahra region of Kuwait. East Mediterr Health J 2005;11:700-6.

18. Saffi $M$, Howard $N$. Exploring the effectiveness of mandatory premarital screening and genetic counselling programmes for $\beta$-thalassaemia in the middle east: a scoping review. Public Health Genomics 2015;18:193-203. 